\title{
PERBANDINGAN DUA EKSTRAKSI YANG BERBEDA PADA \\ DAUN KELOR (Moringa oleifera, lamk) TERHADAP \\ RENDEMEN EKSTRAK DAN SENYAWA BIOAKTIF YANG DIHASILKAN
}

\author{
Agung Abadi Kiswandono \\ Universitas Prima Indonesia Medan \\ Email : nau_shila@yahoo.com \\ ABSTRACT \\ Effect of Two Extract Methods on Content and Compound of Leaf \\ of Kelor (Moringa oleifera,Lamk) \\ By. Agung Abadi Kiswandono
}

\begin{abstract}
It had been studied to identify and compare bia active coumpound group and extract content that had been produced of kelor leaf (Moringa oleifera,Lamk) using maserasi extract method and reflux method with methanol and hexane solution respectively. The content produced by reflux with hexane solution was $11.406 \%$ and with methanol was $12.806 \%$. The content produced by maseration with hexane was $9.976 \%$ and with methanol was 11,863\%. Statistical analysis using T-Test resulted that reflux method and maseration method using hexane solution was significantly different in eror level $5 \%$, but by using methanol was not significanntly diferent in $5 \%$ eror level. Phytochemistry test for leaf powder had bioactive compound of steroid,tanin, phenol hydroquinon and saponin. In methanol extract of reflux method had bioactive compound of alkaloid, phenolhydroquinon, flavonoid, steroid,triterpenoid, tanin, and saponin, while in maseration method was alcaloid, steroid,tanin, and saponin.
\end{abstract}

Keywords : Moringa oleifera, reflux,maseration, bioactive, phytochemical

\begin{abstract}
ABSTRAK
Telah dilakukan penelitian dengan tujuan mengidentifikasi dan membandingkan golongan senyawa bioaktif dan rendemen ekstrak yang dihasilkan pada daun kelor (Moringa oleifera, Lamk) dengan metode ekstraksi maserasi dan refluks menggunakan pelarut heksana dan metanol 80\%. Rendemen yang dihasilkan dengan metode refluks menggunakan pelarut heksana adalah 11,406\% dan metode maserasi $9,976 \%$, sedangkan dengan pelarut Metanol $80 \%$, metode refluks $12,808 \%$ dan metode maserasi $11,863 \%$. Uji $\mathrm{t}$ antara metode refluks dan maserasi daun kelor menggunakan pelarut heksana berbeda nyata dan menggunakan pelarut metanol $80 \%$ tidak berbeda nyata pada taraf nyata 5\%. Hasil uji fitokimia pada serbuk daun mengandung senyawa bioaktif steroid, tanin, fenol hidroquinon dan saponin. Pada ekstrak metanol 80\%, metode refluks adalah golongan alkaloid, fenol hidrokuinon, flavonoid, steroid, triterpenoid, tanin, dan saponin sedangkan pada maserasi adalah golongan alkaloid, fenol hidrokuinon, flavonoid, steroid, tanin, dan saponin.
\end{abstract}

Kata kunci : Moringa oleifera, refluks, maserasi, bioaktif, fitokimia.

\section{PENDAHULUAN}

Tumbuhan Kelor (Moringa oleifera, Lamk) adalah sejenis tumbuhan yang tumbuh baik di daerah tropis dan telah banyak dikenal masyarakat dulu sebagai sayuran dan obat tradisional. Tanaman kelor atau marongghi (Moringa oleifera), berasal dari kawasan sekitar Himalaya dan India, kemudian menyebar ke kawasan di sekitarnya sampai ke Benua Afrika dan Asia-Barat, termasuk Indonesia.

Tumbuhan umumnya mengandung senyawa - senyawa kimia yang banyak ragamnya. Senyawa kimia di dalam tumbuhan dibentuk dan diuraikan melalui dua sistem metabolisme, yaitu metabolisme primer dan metabolisme sekunder. Proses metabolisme primer melibatkan senyawa metabolit primer, seperti karbohidrat, protein, lipid dan asam nukleat. Sedangkan metabolisme sekunder menghasilkan produk berupa metabolit sekunder, seperti alkaloid, flavonoid, tanin, terpenoid, steroid dan lain-lain. Beberapa penelitian membuktikan bahwa kandungan senyawa pada Moringa oleifera L berpotensi sebagai obat dan mempunyai bioaktivitas, diantaranya mempunyai aktivitas sebagai antiimflamasi (Sashidhara et al. 2007), antifungi (Chuang et al. 2006), antibiotik (Eilert et al. 2007) dan antikanker (Jayavardhanan et al. 1994), serta antioksidan (Benabdesselam et.al. 2007).

Pada proses pemisahan senyawa bioaktif, pemilihan metode pemisahan senyawa merupakan hal yang penting untuk diperhatikan, karena pada proses pemisahan ini akan ditentukan berapa besar rendemen yang dihasilkan. Ekstraksi atau pemisahan senyawa kimia dari sumber tanaman 
merupakan awal proses isolasi senyawa bioaktif yang berada pada tumbuhan, baik pada daun, biji, akar ataupun batang (Sidik, 1977). Beberapa pelarut organik yang sering digunakan sebagai ekstraktan seperti benzena, toluena, petroleum eter, metilenklorida, klorofrom, karbon tetraklorida, etil asetat dan dietil eter. Dalam pemilihan pelarut, halhal yang perlu dipertimbangkan adalah selektifitas, sifat racun dan kemudahannya untuk diuapkan. Alkohol merupakan pelarut yang baik untuk ekstraksi pendahuluan (Harborne, 1996). Pelarut bersifat non polar akan melarutkan sebagian besar senyawa polar, begitu pula dengan pelarut polar akan melarutkan senyawa yang bersifat polar (Simanjuntak, 1988).

Ekstraksi digunakan untuk memperoleh kandungan senyawa kimia yang larut pada pelarut. Ada beberapa macam ekstraksi yang biasa digunakan pada proses pemisahan senyawa bioaktif dari tumbuhan dalam rangka mengetahui rendemen yang akan dihasilkan, yakni ekstraksi cara dingin yang terdiri dari maserasi, perkolasi dan sokletasi serta ekstraksi cara panas, yakni dengan cara refluks.

Ekstraksi secara dingin pada prinsipnya tidak memerlukan pemanasan. Hal ini diperuntukkan untuk bahan alam yang mengandung komponen kimia yang tidak tahan terhadap pemanasan dan bahan alam yang mempunyai tekstur yang lunak, misalnya pada daun dan bunga. Kelebihan metode ini adalah sederhana, tidak memerlukan alat-alat yang rumit, relatif murah. Kelemahannya adalah dari segi waktu dan penggunaan pelarut yang tidak efektif dan efisien. Untuk metode ekstraksi secara panas adalah refluks dimana metode ini berkesinambungan, cairan penyari kontinyu menyari zat aktif dalam simplisia. Cairan penyari dipanaskan sehingga menguap dan uap tersebut dikondensasikan oleh pendingin balik, sehingga mengalami kondensasi menjadi molekul-molekul cairan dan jatuh kembali ke dalam labu alas bulat sambil menyari simplisia, proses ini berlangsung secara berkesinambungan dan biasanya dilakukan 3 kali dalam waktu 4 jam. Sampel yang biasanya diekstraksi adalah sampel yang mempunyai komponen kimia yang tahan terhadap pemanasan dan mempunyai tekstur yang keras, misalnya pada biji, kulit dan akar.

Dalam pengembangan obat tradisional menjadi sediaan fitofarmaka, kepastian akan kandungan zat aktif yang berkhasiat merupakan tuntutan kreteria yang harus dipenuhi. Pemberian informasi tentang efektifitas proses pemisahan senyawa bioaktif sangatlah penting bagi dunia farmasi.

Berdasarkan uraian di atas, maka telah dilakukan ekstraksi senyawa bioaktif pada daun Moringa oleifera dengan fokus membandingan proses pemisahannya, yakni dengan cara dingin (menggunakan proses maserasi) dan dengan cara panas (menggunakan proses refluks).

\section{METODE PENELITIAN}

\section{Bahan}

Sampel daun kelor diambil pada bulan Maret dari desa Cikarang kecamatan Dramaga, Bogor. Zat kimia yang dipakai semua pure analysis, yaitu metanol, heksana, satu set pereaksi uji fitokimia (terdiri dari uji alkaloid, terpenoid, flavonoid, saponin dan tanin), kertas saring, akuades, aluminium foil, kapas bebas lemak dan tisu.

\section{Peralatan}

Alat yang digunakan adalah satu set alatalat gelas, alat ekstraksi refluks dan maserasi, oven, labu penguap putar, blender, neraca analitik, desikator, refrigerator dan satu set alat untuk uji fitokimia.

\section{Prosedur Kerja}

Sampel daun kelor yang didapatkan, kemudian dibersihkan dari kotoran-kotoran dan dikeringkan di udara terbuka. Sampel yang telah kering lalu dihaluskan dengan menggunakan blender, kemudian dihitung kadar airnya dan dilakukan proses ekstraksi cara dingin dan panas.

\section{$\underline{\text { Ekstraksi Dingin (Maserasi) }}$}

Sebanyak 20 - 25 g sample kering yang telah dihaluskan dimaserasi dengan heksana sampai bebas lemak. Ekstraksi dilakukan sebanyak 4 kali ulangan. Ekstrak yang dihasilkan disaring, kemudian filtratnya di pekatkan dengan menggunakan labu penguap putar pada suhu $40^{\circ} \mathrm{C}$ sehingga diperoleh ekstrak kasar dan dihitung rendemennya. Ampasnya dikering anginkan lalu setelah kering, dimaserasi kembali dengan metanol $80 \%$ dengan cara yang sama seperti heksana. Filtrat yang dihasilkan lalu dipekatkan dan didapatkan ekstrak kasar dan dihitung rendemennya. 


\section{Ekstraksi Panas (Refluks)}

Sebanyak 20 - 25 g sample kering yang telah dihaluskan dimasukkan kedalam labu bulat, ditambahkan heksana secukupnya dan direfluks selama 7 jam. Ekstraksi dilakukan sebanyak 4 kali ulangan. Ekstrak yang dihasilkan disaring, kemudian filtratnya di pekatkan dengan menggunakan labu penguap putar pada suhu $40{ }^{\circ} \mathrm{C}$ sehingga diperoleh ekstrak kental dan dihitung rendemennya. Ampasnya dikering anginkan lalu setelah kering, direfluks kembali menggunakan metanol $80 \%$ dengan cara yang sama seperti heksana. Filtrat yang dihasilkan lalu dipekatkan sehingga didapatkan ekstrak kasar dan dihitung rendemennya.

Ekstrak metanol $80 \%$ yang dihasilkan dari proses maserasi dan refluks serta sampel serbuk daun kelor diuji fitokimia untuk mengetahui golongan senyawa bioaktif. Uji fitokimia yang dilakukan meliputi uji kualitatif untuk alkaloid, triterpenoid-steroid, saponin, flavonoid, dan tanin.

\section{HASIL DAN PEMBAHASAN}

Bagian tumbuhan yang digunakan dalam penelitian ini adalah daun. Daun kelor yang sudah kering lalu dihaluskan dengan menggunakan blender. Tujuannya adalah untuk memperluas permukaan sampel sehingga pada tahap ekstraksi, interaksi antara pelarut pengekstrak dengan sampel yang diekstraksi menjadi lebih efektif dan pelarut pengekstrak akan lebih mudah mengambil zat-zat yang terkandung dalam sampel. Sampel yang digunakan pada penelitian ini merupakan bahan yang berasal dari tumbuh-tumbuhan, sehingga sampel mengandung air yang jumlahnya relatif tinggi. Oleh karena itu, dalam tahap persiapan sampel harus dilakukan penentuan kadar air.

Kadar air sampel daun widuri masih terlalu tinggi, yakni adalah 17,653\%. Menurut Winarno (1997), sampel yang baik untuk disimpan dalam jangka panjang adalah jika kadar air sampel kurang dari $10 \%$. Hal yang sama, pernah didapatkan oleh Budiman (2001), yakni 11,92\% dengan sampel kering giling dari tumbuhan $A$. sacrorum Ledeb dan Wulandari (2005) memperoleh 13,25\% dengan sampel buah mahkota dewa. Kadar air dalam penelitian ini lebih dari $10 \%$, oleh karena itu sampel tidak bisa digunakan dalam jangka waktu yang lama karena memungkinkan timbulnya jamur. Untuk menghindari hal tersebut maka sampel disimpan di dalam freezer.

\section{Pemisahan Senyawa Bioaktif dan Uji Fitokimia}

Dalimartha (2003) menyatakan bahwa toksisitas tanaman berhubungan dengan metabolit sekunder yang terkandung di dalamnya. Oleh karena itu uji fitokimia secara kualitatif dilakukan sebagai uji awal untuk mengetahui keberadaan senyawa kimia spesifik.

Pemisahan golongan senyawa bioaktif pada penelitian ini menggunakan metode maserasi dan refluks. Mekanisme metode maserasi adalah proses difusi pelarut ke dalam dinding sel tumbuhan untuk mengekstrak senyawa-senyawa yang ada dalam tumbuhan tersebut. Metode maserasi digunakan untuk mengekstrak senyawa yang kurang tahan terhadap panas, biasanya digunakan untuk sampel yang belum diketahui karakterisasi senyawanya, sedangkan Metode refluks menggunakan efek panas untuk membantu proses difusi pelarut ke dalam dinding sel tumbuhan.

Pelarut yang digunakan pada masingmasing sampel adalah heksana dan metanol $80 \%$. Senyawa yang akan terbawa pada proses ini adalah senyawa-senyawa yang memiliki polaritas yang sesuai dengan pelarut yang digunakan. Pelarut heksana adalah pelarut non polar, sehingga senyawa-senyawa yang larut juga berfsifat non polar, sedangkan metanol $80 \%$ adalah pelarut yang bersifat polar, digunakan untuk menarik senyawasenyawa yang bersifat polar. Pemisahan pertama terhadap sampel digunakan pelarut heksana dengan tujuan untuk memisahkan senyawa-senyawa non polar termasuk lemak yang terkandung pada sampel. Setelah diperoleh ekstrak kasar metanol $80 \%$, lalu di lakukan uji fitokimia.

Uji fitokimia bertujuan untuk melakukan keberadaan terhadap beberapa senyawa bioaktif yang terkandung dalam sampel. Uji fitokimia yang dilakukan pada serbuk daun, serta pada ekstrak metanol 80\% daun adalah uji alkaloid, flavonoid, steroid, triterpenoid, tanin, phenol hidroquinon dan saponin.

Adanya alkaloid pada sampel ditunjukkan dengan terdapatnya endapan putih dengan pereaksi Mayer, endapan merah jingga dengan pereaksi Dragendroff, dan endapan coklat dengan pereaksi Wagner. Adanya phenol hidroquinon ditunjukkan dengan warna merah saat penambahan $\mathrm{NaOH}$ $10 \%$. Adanya steroid ditunjukkan dengan warna hijau pada lapisan eter yang ditambahkan dengan pereaksi Liebermenn-burchad. Adanya tanin ditunjukkan atau ditandai dengan adanya warna biru tua atau hijau kehitaman, sedangkan adanya saponin pada sampel ditunjukkan dengan 
terbentuknya busa yang stabil pada filtrat yang ditutup serlama 10 menit pada tabung reaksi.

Tabel 1. Hasil Uji Fitokimia Serbuk Daun Kelor

\begin{tabular}{l|c}
\hline \multicolumn{1}{c|}{ Uji Fitokimia } & Serbuk Daun \\
\hline Alkaloid & - \\
Fhenol hidrokuinon & + \\
Flavonoid & - \\
Steroid & ++ \\
Triterpenoid & - \\
Tanin & +++ \\
Saponin & ++ \\
\hline
\end{tabular}

$$
\begin{aligned}
\text { Keterangan : }- & : \text { negatif (tidak terdapat senyawa } \\
& \text { bioaktif) } \\
+ & \text { positif menyatakan intensitas } \\
& \text { warna/endapan }
\end{aligned}
$$

Hasil uji fitokimia pada Tabel 1 menunjukkan bahwa, pada sampel serbuk daun kelor mengandung senyawa metabolit sekunder fenol hidrokuinon, steroid, tanin, dan saponin. Dalam hal ini terlihat bahwa senyawa tanin mempunyai intensitas yang paling besar. Tetapi, hasil uji fitokimia terhadap ekstrak daun dengan metode refluks dan maserasi (Tabel 2) terlihat, bahwa senyawa alkaloid muncul dengan intensitas yang paling besar, walaupun pada awalnya, yakni pada uji fitokimia serbuk daun, golongan senyawa ini negatif.

Munculnya senyawa alkaloid pada ekstrak metanol $80 \%$ menunjukkan bahwa, pelarut polar (metanol 80\%) dapat mengekstrak atau menarik senyawa golongan alkaloid, flavonoid, dan triterpenoid, dengan sangat baik. Alasan lainnya, bahwa pemisahan pertama yang dilakukan dengan pelarut non polar (heksana), dapat membantu memunculkan golongan senyawa-senyawa tersebut, karena heksana dapat melarutkan lemak, minyak dan senyawa-senyawa non polar lainnya yang dapat mengganggu munculnya golongan senyawa tersebut pada saat pengujian fitokimia serbuk daun.

Hasil pengujian terhadap sampel menunjukkan, bahwa daun kelor mengandung alkaloid, phenol hidroquinon, flavonoid, steroid, tanin dan saponin sehingga daun kelor berpotensi sebagai antioksidan (Pratt and Hudson 1990, Benabdesselam et.al. 2007). Beberapa peneliti juga menyatakan, bahwa tumbuhan kelor atau Moringa oleifera L adalah salah satu tumbuhan yang berpotensi sebagai antioksidan (Siddiq et.al. 2005, Chumark et al. 2007, Sato et.al., 2002, Kumar dan Pari, 2003). Senyawa tersebut berperan sebagai antioksidan dengan cara menghambat peroksida lipid sehingga dapat melindungi tubuh dari penyakit kanker. Sampel biji kelor juga berpotensi sebagai penurun kolesterol dan dapat memperkecil resiko arteroskeloris pada diabetes karena mengandung saponin (Rafi, 2003) juga berpotensi sebagai penurun kadar glukosa darah karena mengandung senyawa bioaktif alkaloid (Hermawan, 2002).

\section{Rendemen Senyawa Bioaktif}

Rendemen adalah perbandingan produk akhir yang diperoleh terhadap bahan baku yang digunakan. Nilai rendemen yang diperoleh berdasar berat kering bahan baku. Rendemen

\begin{tabular}{|c|c|c|}
\hline Uji Fitokimia & Metode Refluks & Metode Maserasi \\
\hline Alkaloid & ++++ & ++++ \\
\hline Fenol hidrokuinon & ++ & ++ \\
\hline Flavonoid & ++ & ++ \\
\hline Steroid & ++ & ++ \\
\hline Triterpenoid & + & - \\
\hline Tanin & ++ & ++ \\
\hline Saponin & ++ & ++ \\
\hline
\end{tabular}
produk berkaitan dengan metode ekstraksi yang dipakai untuk memisahkan senyawa bioaktif.

Tabel 2. Hasil Uji Fitokimia dengan Metode Refluks dan Maserasi Menggunakan Pelarut Metanol 80\% 

Metode ekstraksi yang digunakan pada penelitian ini adalah maserasi (ekstraksi dingin) dan refluks (ekstraksi panas). Hal ini dilakukan dengan tujuan untuk melihat pengaruh proses ekstraksi yang berbeda-beda terhadap rendemen dan golongan senyawa bioaktif yang dihasilkan.

Rendemen yang diperoleh dari hasil ekstraksi pada sampel daun (Tabel 3) menunjukkan bahwa metode refluks dengan pelarut heksana memiliki rendemen lebih besar yakni 11,406\% dibandingkan metode maserasi dengan rendemennya hanya $9,976 \%$.

Hal yang sama juga terjadi dengan pelarut Metanol 80\%. Rendemen yang diperoleh dari hasil ekstraksi pada sampel daun (Tabel 4) menunjukkan bahwa metode refluks mempunyai rendemen yang lebih besar, yakni 12,808\% dibandingkan metode maserasi yang hanya menghasilkan 11,863\%. Dari tabel 4, tabel 5 dan gambar 1, terlihat bahwa perbedaan rendemen yang diperoleh pada ekstraksi daun kelor dengan metode refluks dan maserasi menggunakan pelarut heksana adalah 1,429\% dan dengan menggunakan pelarut metanol $80 \%$ adalah $0,945 \%$.

Uji t antara metode refluks dan maserasi daun kelor menggunakan pelarut metanol 80\% didapatkan bahwa nilai-p adalah 0,111 . Karena nilai-p lebih besar dari taraf nyata $(\alpha) 5 \%$, maka kesimpulannya terima $\mathrm{H}_{0}$ artinya antara metode refluk-heksana dan maserasi-heksana tidak berbeda nyata pada taraf nyata 5\%, atau untuk menarik kesimpulan dapat dilihat dari nilai-t (t hitung), yakni nilai $\mathrm{t}$ hitung didapat sebesar 2,24, sedangkan nilai t-tabel dengan $\mathrm{df}=5$, dan $\alpha=5 \%$ diketahui adalah 2,571. Karena nilai t hitung < dari t-tabel maka kesimpulannya terima $\mathrm{H}_{0}$ artinya tidak terdapat perbedaan diantara kedua metode tersebut.

Dengan demikian bahwa proses pemanasan pada sampel daun kelor secara kuantitatif dapat menyebabkan senyawa terlarut lebih banyak terekstrak dari pada tanpa proses pemanasan. Hal ini disebabkan karena adanya efek panas pada metode refluks. Adanya efek panas ini akan menyebabkan naiknya energi kinetika pelarut dan komponen-komponen dalam tumbuhan, sehingga akan meningkatkan frekuensi tumbukan diantara keduanya. Tumbukantumbukan ini sangat diperlukan terutama dalam mempercepat proses destruksi dinding sel, difusi pelarut kedalam dinding sel dan pelarutan senyawa-senyawa tumbuhan dalam pelarut yang digunakan (Hidayat, 2004).

Secara uji statistik tidak terdapat perbedaan nyata antara metode refluks dan maserasi dengan menggunakan pelarut metanol $80 \%$, tetapi metode refluks dari segi waktu memiliki efisiensi ekstraksi yang lebih singkat dibandingkan dengan metode maserasi. Proses ekstraksi dengan refluks memerlukan waktu 4 x 2 jam, sedangkan dengan maserasi memerlukan waktu hampir 3 x 24 jam. Kemudian dari segi pelarut yang digunakan, metode maserasi relatif menggunakan pelarut lebih banyak dibandingkan dengan metode refluks.

Tabel 3. Rendemen pada Sampel dengan Pelarut Heksana

\begin{tabular}{lccc}
\hline & \multicolumn{2}{c}{ Rendemen (\%) } & \multirow{2}{*}{$\begin{array}{c}\text { Selisih } \\
\text { Sampel }\end{array}$} \\
\cline { 2 - 3 } (ke dua metode)
\end{tabular}


Tabel 4. Rendemen pada Sampel dengan Pelarut Metanol 80\%

\begin{tabular}{lccc}
\hline \multirow{2}{*}{ Sampel } & \multicolumn{2}{c}{ Rendemen $(\%)$} & \multirow{2}{*}{$\begin{array}{c}\text { Selisih } \\
\text { (ke dua metode) }\end{array}$} \\
\cline { 2 - 3 } & Metode Refluks & Metode Maserasi & \\
Ulangan 1 & 11,830 & 9,982 & \\
Ulangan 2 & 11,121 & 9,716 & 1,429 \\
Ulangan 3 & 11,747 & 9,833 & \\
Ulangan 4 & 10,924 & 10,374 & \\
Rata-rata & 11,406 & 9,976 & \\
\hline
\end{tabular}

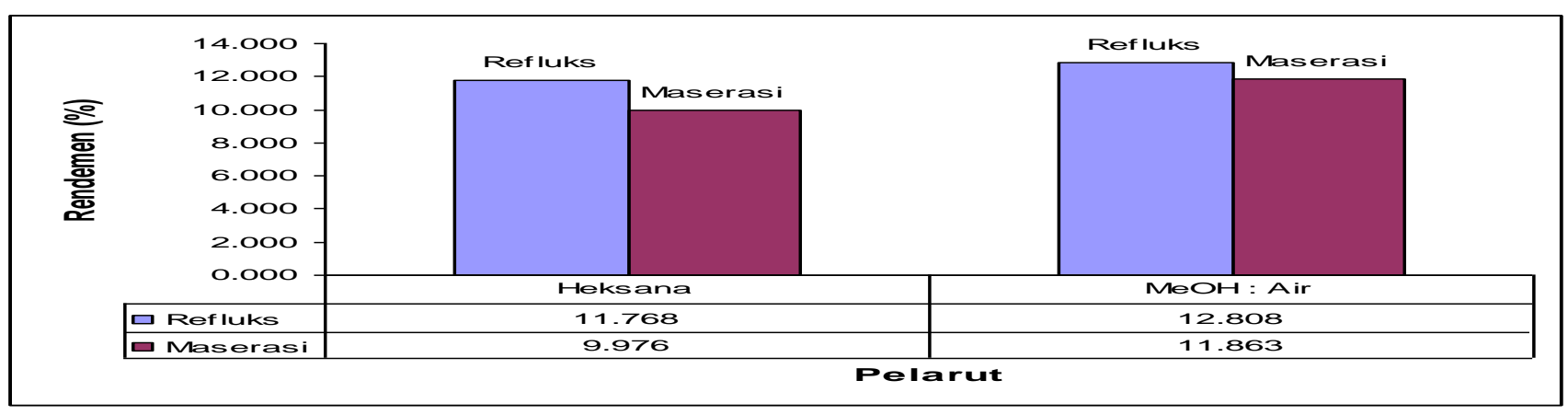

Gambar 1. Perbandingan rendemen pada sampel menggunakan pelarut heksana dan Metanol 80\% dengan metode refluks dan maserasi

\section{KESIMPULAN}

Golongan senyawa bioaktif pada ekstrak daun dengan pelarut metanol $80 \%$ dengan refluks adalah alkaloid, fenol hidroquinin, flavonoid steroid, triterpenoid, tanin dan saponin sedangkan dengan maserasi adalah alkaloid, fenol hidroquinin, flavonoid steroid, tanin dan saponin. Rendemen sampel daun menggunakan metode refluks dan pelarut heksana adalah $11,406 \%$ sedangkan maserasi $9,976 \%$. Rendemen dengan pelarut metanol $80 \%$ pada metode refluks sebesar $12,808 \%$ dan maserasi $11,863 \%$. Uji t antara metode refluks dan maserasi daun kelor menggunakan pelarut heksana berbeda nyata pada taraf nyata $5 \%$ dan menggunakan pelarut metanol $80 \%$ tidak berbeda nyata pada taraf nyata $5 \%$.

\section{UCAPAN TERIMA KASIH}

Ucapan terima kasih kepada Kopertis Wilayah I NAD-SUMUT yang telah membiayai penelitian ini. Terima kasih juga kepada Dewi Wulandari, MS., Dekan FMIPA Universitas Tri Karya Medan, DR. Dyah Iswantini, M.Agr. dosen
Sekolah Pascasarjana Kimia IPB Bogor yang telah membimbing selama penelitian ini berlangsung.

\section{DAFTAR PUSTAKA}

Benabdesselam FM. Et. al. 2007. Antioxidant activities of alkaloid extracts of two Algerian species of Fumaria : Fumaria capreolata and Fumaria bastardii. ACG Publication Rec. Nat. Prod. 1:2-3 (2007) 28-35

Budiman, A. 2001. Senyawa Bioaktif Golongan Kumarin Artemisia Sacrorum Ledeb. Skripsi. FMIPA. IPB. Bogor.

Chuang PH et al. 2006. Anti-fungal activity of crude extracts and essential oil of Moringa oleifera Lam. Journal of Bioresource Technology 98 (2007) 232236.

Chumark $\mathrm{P}$ et al. 2007. The in vitro and ex vivo antioxidant properties, hypolipidaemic and antiatherosclerotic activities of water 
extract of Moringa oleifera Lam. Leaves. Journal of Ethnopharmacology 116 (2008) $439-446$.

Dalimarta, S. 2003. Karakteristik Tumbuhan Obat di dalam Prosiding Seminar dan Pameran Nasional Tumbuhan Obat Indonesia XXIV. Pusat Studi Biofarmaka IPB. Bogor.

Eilert U, Wolters B \& Nahrstedt A. 1981, The antibiotic principle of seeds of Moringa oleifera and Moringa stenopetala. $J$. Medicinal Plant Res., 42 pp55-61.

Harborne, J. B. 1996. Metode Fitokimia. Cara modern menganalisa Tumbuhan. Terjemahan Kosasih Patmawinata dan Iwang Soediro. Edisi ke 3. Penerbit ITB. Bandung.

Hermawan, H. 2002. Isolasi dan Pencirian Senyawa Aktif dari Tumbuhan Antinganting (Acalypha indica L.) yang Berpotensi Menurunkan Kadar Glukosa Darah. FMIPA. IPB. Bogor.

Hidayat, MG. 2004. Perbandingan Metode Ekstraksi Flavonoid dan Terpenoid dari Sidaguri Serta Daya Inhibisi Ekstrak Terhadap Aktivitas Xantin Oxidase. Skripsi. FMIPA. IPB. Bogor.

Jayavardhanan KK, Suresh K, Panikkar KR. \& Vasudevan DM. 1994, Modulatory potency of drumstick lectin on the host defense system. Exp. Clin. Cancer Res., 13 (3) pp205- 209.

Kumar, NA \& Pari, L. 2003 Antioxidant Action of Moringa oleifera Lam. (Drumstick) Against Antitubercular Drugs Induced Lipid Peroxidation in Rats. Journal of Medicinal Food. 6 (3) : 255 - 259.

Prat DE, BJF. Hudson. 1990. Natural Antioxidant not Exploited Commercially. Didalam BJF Hudson. Editor Food Antioxidant. Elsevier Science. London.
Rafi, M. 2003. Identifikasi Fisik dan Senyawa Kimia Pada Tumbuhan Obat Fokus Untuk Tumbuhan Obat Diabites Melitus. Dalam makalah Pelatihan Tanaman Tradisional (swamedikasi) Pengobatan Penyakit Diabites Melitus. Pusat Studi Biofarmaka. IPB. Bogor.

Sashidhara KV et. al. 2008. Rare dipeptide and urea derivatives from roots of Moringa oleifera as potential anti-inflammatory and antinociceptive agents. Short communication. European Journal of Medicinal Chemistry xx (2008) 1e5.

Sato, T et al. 2002, Evaluation of antioxidant activity of indigenous vegetables from South and Southeast Asia. JIRCAS Research Highlights.

Simanjuntak, P. 1988. Metode Isolasi dan Pemurnian Ekstrak Air dari Tumbuhan. Warta $A K A B$.

Sidik M. 1997. Antioksidan Alami Asal Tumbuhan. Prosiding Seminar Nasional Tumbuhan Obat Indonesia XII. Bandung. ITB.

Siddiq A et al. 2005. Antioxidant activity of different solvent extracts of Moringa oleifera leaves under accelerated storage of sunflower oil. Asian Journal of Plant Sciences 4(6) 630-635.

Wulandari, NDM. 2005. Perbandingan Metode Ekstraksi Buah Mahkota Dewa (Phaleria macrocarpa) dan Uji Toksisitas Subkronis Pada tikus Putih (Skripsi). FMIPA. IPB. Bogor.

Winarno, WP. 1997. Kimia Pangan dan Gizi. Gramedia. Jakarta. 